\title{
The Path of Football Culture construction in Jiang Xi Independent College
}

\author{
Chen Huan, Zhu Rui, Guo Yifeng \\ Nanchang University College of Science and Technology, Jiangxi, 330029, China
}

Keywords:football culture;jiang xi; School

\begin{abstract}
Football culture has the value of education, entertainment and construction. It is an important force in the construction of university culture and an organic component of the cultural connotation of colleges and universities. With the development of the National Football League, football is more and more popular among the teachers and students in Colleges and universities. Although the football is popular, the construction of the campus football culture did not keep pace with the development of the football activities.Here we take the Jiang Xi independent college as an example, analyzed the main problems of campus culture construction and put forward some suggestions of the dissemination of campus football culture, hoping to provide some reference for the development of campus football culture. To explore the connotation of college football culture from the cultural perspective, and on the basis of discussing the significance of the construction of campus football culture, this paper expounds the construction of the university football culture path from the value orientation, system norms and practice inside and outside the classroom once. So as to promote the development of campus football culture in a more scientific and more important direction, and it will be of guiding significance and reference value for the construction of campus football culture.
\end{abstract}

\section{Introduction}

Campus is a unique cultural institution, and its essential character is its internal culture and spirit. The highest expression of university culture is the spirit of the University. The spirit of the university has a series of extremely important functions, such as value orientation, spiritual cultivation, normative restriction, group cohesion and social radiation., and the core of university culture is a sound personality for the benefit of mankind[1]. As an important base for the creation and dissemination of advanced culture, the main task of campus is to cultivate talents excellent in character and guide the healthy development of the society. As part of campus culture, school physical education is an integral part of overall development education[2]. Only Germany, wisdom, body and beauty combine with each other and promote each other to form the complete content of a modern generation with ideals, morality, culture, discipline and strong physique[3]. As a kind of culture on campus, football culture combines fun, beauty, and writing in one. In the process of cultivating all-round talents,combine football culture with university culture and university spirit has irreplaceable special role.

Under the guidance of the traditional educational philosophy for a long time, the majority of our colleges and universities have not paid enough attention to the football course. Students think that football is just a subordinate part of the physical education curriculum, and sports course itself does not have too big effect to the students, their main task is to study in culture. Obviously, under the influence of this idea, the development of soccer culture in our country is slow, and most of the students have a low level of cognition about football knowledge and skills[4]. To improve this situation, the great importance of football culture construction should be mentioned, what's more, the basic knowledge and skills of College students should be popularized, then build a healthy, all-round development of the outstanding football talents team[5]. As an integral part of the national universities, Jiangxi independent college should pay attention to the construction of football culture. 


\section{The significance of football culture construction in Jiang Xi independent college}

\section{The impact on students}

As a part of the cultural construction in Jiang $\mathrm{Xi}$ independent colleges, the development of football culture and the whole culture in the univercity is complementary. The growth of the campus football culture plays an important role to students, its effect is mainly manifested as follows:

1). Football culture is good for developing students' good will quality. Generally speaking, a football match lasted about 1.5 hours, in the course of the game, the students' physical qualities (such as endurance) will face enormous challenges. In order to win the game, students will often try to persist, it helps cultivate their perseverance, indomitable spirit of quality, in addition, in the standardization of the football game, the students not only to win the honor for our team, but also to follow the rules of the game, which will help them to establish a correct sense of competition.

2). The construction of football culture in universities is beneficial to train and improve students' team cooperation ability. Football is an international competitive sports, in the process of football, team members need to cooperate with each other and use flexible collective tactics to defeat each other. For this kind of collective sports, it is impossible to win by relying on one's own strength. Only through teamwork and coordination can the team win the final victory. This will enable students to appreciate the importance of teamwork and improve their team work skills.

3). Football culture in Colleges and universities enables students to integrate into society better after graduation. On one hand, students participating in the football match at school can recognize more golfers, talk and build friendship with each other, which expands the students' social circle and exercises their social skills. On the other hand, the students will often watch football world football event such as the Asian Cup, world cup in the school, which will enable students to understand the society from all walks of life, even the world football fans. Then establish a wider social circle, which lay the foundation for a better integration into society.

\section{The impact of football culture construction on the development of China's football industry}

As everyone knows, the overall level of the development of football in China is low, and the world competition record of china was also poor, which further for football culture construction in Colleges and universities in China has sounded the alarm, constructing the good campus football culture, can not only provide the guarantee for the healthy development of students, but also can provide a good cultural environment for the construction of football talents in china. At present, the development of football occupation club in China is facing many problems, including the lack of players and low quality. It would be necessary to do a good job in college football culture. To train a large number of excellent football players from colleges and universities, so that they can set up ambitious goals for China's football career

\section{The problems of football culture construction in Jiangxi Independent College}

\section{Football foundation of students is weak}

Judging from the current situation, football is poorly understood by students in univercity, some students even did not come into contact with football class, which leads them to skeptical of football culture, do not understand what is the role of football for them . Since the football foundation of students is weak, their training processes are often unable to grasp the basic essentials of football, learning enthusiasm is not high. Once encountered injuries and other accidents, they may easily give up, so that not only can not play the role of physical exercise, but also made a bad impression on the students' football, eventually hinder the cultural construction of college football forward.

\section{Football curriculum is unreasonable}

Football curriculum is the main way for students to learn basic knowledge of football. Only by scientific and reasonable curriculum setting can students really master the knowledge and skills of 
football theory, while judging from the current situation of football curriculum in colleges and universities, the football curriculum in most colleges and universities is irrational. The problem is mainly manifested in the following aspects:

1). As shown in Table 1, the number of football courses is not reasonable. Influenced by the traditional teaching ideas, schools generally think that football curriculum is unimportant to students, therefore, in the setting of the number of courses, it often lays stress on cultural courses. According to the survey, nearly $80 \%$ of the college timetable in our country arranges only one football lesson each week, while other cultural classes have at least two sessions per week. That's enough to see the school's contempt for soccer lessons.

Table1.Football course hour questionnaire

\begin{tabular}{cccc}
\hline Survey content & Too much learning time & Enough learning time & Too little learning time \\
\hline Number & 250 & 426 & 324 \\
\hline Percentage & $25 \%$ & $42.6 \%$ & $32.4 \%$ \\
\hline
\end{tabular}

2). The time setting of the football lessons is not appropriate

As shown in Table 2, most of students think that the football class should be take earlier since our football class always the last one.

Table2.Football course time setting questionnaire $(\mathrm{N}=1000)$

\begin{tabular}{cccc}
\hline Survey content & Too late & Reasonable & Too early \\
\hline Number & 730 & 101 & 169 \\
\hline Percentage & $73 \%$ & $10.1 \%$ & $16.9 \%$
\end{tabular}

Most football classes are arranged in the morning or afternoon the last lesson, because the previous lesson already consumes more energy, when the last section of the football course will inevitably feel tired, tired, especially in the morning of the last class, most students will be hungry again. And some students do not eat breakfast habits, in the face of morning of the last day of class is not in the state, only looking forward to the early class. This unreasonable time setting only allows students to learn the efficiency and quality of football skills greatly reduced.

3). College football elective curriculum is unreasonable.

The general course of football elective courses of Public Physical Education in colleges, for elective courses, students have a lot of autonomy, in the course will be relatively free, but the vast majority of colleges and universities in China are in accordance with their time in class to college elective course, which leads to some love football the students don't choose football class, and selected football course students do not love football class. In a word, the irrationality of football curriculum has become one of the key factors hindering the construction of football culture.

\section{The propaganda of football culture is not enough}

As shown in Figure 1, about $45 \%$ od students think that football class is boring and $28 \%$ of students think its too professional. This is led by the lack of propaganda. So we should make efforts on it. 


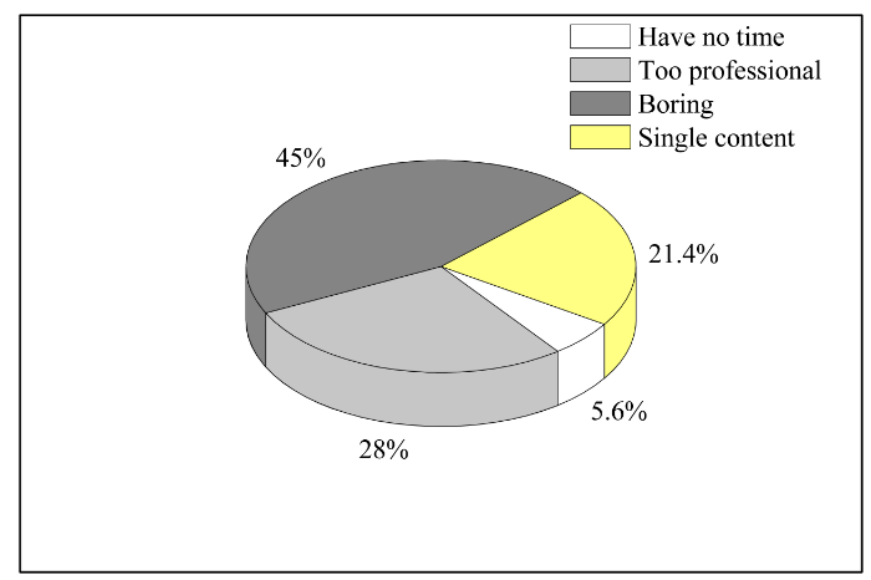

Figure 1.The reasons students do not want to have a football class

The football culture is different from the general culture, it is a special type of culture both wisdom and innovation, is a kind of culture of the people in order to promote the development of football and construction, for a country, football level is not only a symbol of the national physical quality, but also represents the national material with the construction of spiritual civilization degree.

As shown in Table 3, as an elective course, football class always can not choosed by the student who love it. What's more, most of students do not know musch about football and football culture.

\begin{tabular}{cccc}
\multicolumn{4}{c}{ Table3.Football culture questionnaire (N=1000) } \\
\hline Survey content & Know much & Know a little & Known nothing \\
\hline Number & 110 & 485 & 405 \\
\hline Percentage & $11 \%$ & $48.5 \%$ & $40.5 \%$ \\
\hline
\end{tabular}

From the current situation of the development of Chinese football, football practitioners less in quantity, quality is generally low, good football player is very few, this is one of the important reasons causing the low quality of college football teaching in china. In addition, China's college football development lacks a good cultural environment, many colleges and universities do not pay attention to football culture propaganda, in the daily teaching, only pay attention to the culture of course of intensive education, neglect of physical education brings to students physical and mental pleasure, some schools will not even built a small football field, think this is a complete waste of time and money, these narrow wrong thinking has seriously hindered the spread of football culture in Colleges and universities.

\section{Analysis of the ways to build football culture}

Campus football culture is a systematic project, involving all aspects of sports work in Colleges and universities. The reality of football culture in Colleges and universities is to publicize and display the spirit, thought and values of football by means of classroom teaching, association and club activities. The construction of university football spirit culture focuses on environment and practice.

\section{Definite the value orientation of football culture construction}

To build the campus football culture, we must strengthen the importance and reform of the educational idea of football in teaching. First of all, for the ideological understanding and acceptance of football culture, we can promote the development of football and the construction of football culture in reality. Colleges and universities should pay attention to the construction and development of the campus football culture, the students can not only enrich extracurricular life, cultivate moral character and regulate the behavior of students, promote students' comprehensive quality, but also has important significance to realize the goal of the construction of campus culture. 


\section{Improve the football infrastructure}

Judging from the current situation, football is poorly understood by students in univercity, some students even did not come into contact with football class, which leads them to skeptical of football culture, do not understand what is the role of football for them . Since the football foundation of students is weak, their training processes are often unable to grasp the basic essentials of football, learning enthusiasm is not high. Once encountered injuries and other accidents, they may easily give up, so that not only can not play the role of physical exercise, but also made a bad impression on the students' football, eventually hinder the cultu

University football venues, equipment and facilities are the basic prerequisite for the construction of football culture, as well as the essential material environment for students to carry out football exercises. The quality of the school have the number of venues and equipment, facilities, these factors will affect the development of college football culture in Colleges and universities should actively carry out the campus football in response to the call of the country, increase funding support to improve the quality of football teaching facilities and sports venues and other related facilities, provide a good football learning environment for college students, so as to carry out the sport and campus football game, dissemination and development of campus football culture better.

\section{Improve the system and rules of football culture}

The role of football culture depends on the protection of the football culture system. The sound university football system and rules are the basic guarantee for the construction of university football culture. This includes two aspects of security construction, on the one hand, the operation of football activities and organizational model, on the other hand, football activities in the norms of behavior. As a high strength and high competition sports, football with vertical personnel involved, space, technology, technology and other elements of the action, to guide and standardize the system and rules of sound, such as security system, system of football rules, effectively restrain regulate participate in football activities and student groups behavior, let participants consciously regulate their thinking and behavior.

\section{Combining physical education with extracurricular practice}

Deepening the football teaching reform, strengthening the football extracurricular training, perfecting the campus football competition system, and actively carrying out the club association activities are the effective measures for the construction and development of university football culture. Football teaching course is an important part of campus football culture. It includes special teaching courses and extracurricular football games. Along with the reform of education, colleges and universities should to improve students' sports culture and the concept for the purpose, so that students not only master the basic skills of football in the classroom, but also can form a correct concept of football, such as soccer skills education, moral and legal education and humanistic spirit education which is an important part of college football culture; community, associations, clubs and other forms to carry out rich football activities, let students in football practice at the same time enjoy the football spirit unique culture, the campus culture perfect together.

\section{Summary}

Campus football culture, as a subculture of social culture, bears the important function of spreading social culture. Therefore, campus football culture should keep close contact with the society, go out and boldly come in. On the basis of doing well in group activities, we should strengthen the construction of school teams.

The school team has a pivotal position in the campus football culture in foreign, they are school spiritual civilization through the window of the competition between universities and participate in various competitions in the society, not only can improve the students' sports level and can expand the visibility of the school, but also can win honor for our school.Internally, it is a magnet for teachers and students of the whole school. It can increase collective cohesion and is the focus of attention and 
comment of the whole school. Obviously, strengthening the construction of the sports team will help to improve the campus football culture awareness and the football atmosphere of the whole school, and play a positive role in promoting and promoting the football in Colleges and universities.

Campus football culture has a bright future, and it plays an important role in college football and even in china. However, it is a complex and systematic project to build a healthy and progressive campus football culture atmosphere, which must be coordinated in many ways.

\section{References}

[1] Wan R S. Identification and development of national traditional sports culture in the context of Globalization[J]. Journal of Nanchang College of Education, 2013.

[2] $\mathrm{Xu} \mathrm{L} \mathrm{Y.} \mathrm{Construction} \mathrm{of} \mathrm{the} \mathrm{university} \mathrm{campus} \mathrm{football} \mathrm{culture[J].} \mathrm{Journal} \mathrm{of} \mathrm{Nanchang} \mathrm{College}$ of Education, 2013.

[3] Yao C L, Chu C Y. On the Present Situation of Chinese Football Culture Construction and Strategy Analysis[J]. Journal of Shangqiu Vocational \& Technical College, 2006.

[4] Zhang G Q. On the Construction of of Chinese Football Culture in New Period[J]. Journal of Hubei Correspondence University, 2008.

[5] Yao C L, Chu C Y. On the Present Situation of Chinese Football Culture Construction and Strategy Analysis[J]. Journal of Shangqiu Vocational \& Technical College, 2006. 